\title{
Article/Artigo
}

\section{Evaluation of the use of real-time PCR for human T cell lymphotropic virus 1 and 2 as a confirmatory test in screening for blood donors}

\author{
Análise do uso da PCR em tempo real para HTLV-1 e 2 como teste confirmatório na triagem \\ de doadores de sangue
}

Rafaela Gomes Andrade ${ }^{1,2}$, Maísa Aparecida Ribeiro ${ }^{1,2}$, Maria Sueli Silva Namen-Lopes ${ }^{1,2}$, Sônia Mara Nunes Silva ${ }^{1}$, Fernando Valadares Basques ${ }^{1}$, João Gabriel Ribas ${ }^{1}$, Anna Bárbara de Freitas Carneiro-Proietti ${ }^{1,2}$ and Marina Lobato Martins ${ }^{1,2}$

\begin{abstract}
Introduction: HTLV-1/2 screening among blood donors commonly utilizes an enzymelinked immunosorbent assay (EIA), followed by a confirmatory method such as Western blot (WB) if the EIA is positive. However, this algorithm yields a high rate of inconclusive results, and is expensive. Methods: Two qualitative real-time PCR assays were developed to detect HTLV-1 and 2, and a total of 318 samples were tested (152 blood donors, 108 asymptomatic carriers, $26 \mathrm{HAM}$ /TSP patients and 30 seronegative individuals). Results: The sensitivity and specificity of PCR in comparison with WB results were $99.4 \%$ and $98.5 \%$, respectively. PCR tests were more efficient for identifying the virus type, detecting HTLV-2 infection and defining inconclusive cases. Conclusions: Because real-time PCR is sensitive and practical and costs much less than WB, this technique can be used as a confirmatory test for HTLV in blood banks, as a replacement for WB.
\end{abstract}

Key-words: HTLV. Blood donors. Real-time PCR. Western blot.

\section{RESUMO}

Introdução: A triagem para HTLV-1/2 em doadores de sangue geralmente utiliza imunoensaio enzimático, seguido de um método confirmatório como Western blot quando o EIA é positivo, mas este algoritmo mostra alta taxa de resultados inconclusivos, e elevado custo. Métodos: Dois ensaios qualitativos de PCR em tempo real foram desenvolvidos para detectar HTLV-1 e 2 e um total de 318 amostras foram testadas por PCR ( 152 de doadores de sangue, 108 de portadores assintomáticos, 26 de pacientes HAM/TSP e 30 de indivíduos soronegativos). Resultados: A sensibilidade e especificidade das PCR em relação aos resultados de WB foram de 99,4\% e 98,5\%, respectivamente. As PCR foram mais eficientes em identificar o tipo viral, a infecção pelo HTLV-2 e úteis para definir casos inconclusivos. Conclusões: Por serem sensíveis, práticas e de custo muito inferior ao do WB, as técnicas de PCR em tempo real podem ser usadas como teste confirmatório do HTLV em bancos de sangue, em substituição ao WB.

Palavras-chaves: HTLV. Doadores de sangue. PCR em tempo real. Western blot.

1. Minas Gerais State Blood Center, Belo Horizonte, MG, Brazil. 2. Interdisciplinary HTLV Research Group, Belo Horizonte, MG, Brazil.

Address to: Dra Marina Lobato Martins. Gerência de Desenvolvimento Técnico Científico. Fundação HEMOMINAS. Al. Ezequiel Dias 321, 30130-110 Belo Horizonte, MG

Phone: 5531 3248-4587; Fax: 5531 3284-9579

e-mail: pesquisa@hemominas.mg.gov.br

Received in 24/09/2009

Accepted in 04/02/2010

\section{INTRODUCTION}

The human T cell lymphotropic virus (HTLV) is nowadays classified into four types: $1,2,3$ and 4 . The type 1 virus (HTLV-1) has been identified on all five continents, and its areas of great prevalence include Japan, Sub-Saharan Africa, Caribbean basin, South America, Melanesia and the Middle East ${ }^{1}$. The type 2 virus (HTLV-2) is endemic in African and American Indian populations $s^{2,3}$, and its worldwide distribution has been ascribed to transmission among intravenous drug users. HTLV-3 and 4 have recently been discovered in a rural area of southern Cameroon $^{4}$ and, at present, they are restricted to that region.

HTLV-1 is etiologically associated with adult T cell leukemia ${ }^{5}$ and with HTLV-associated myelopathy/ tropical spastic paraparesis (HAM/TSP) ${ }^{6}$, which is a chronic neurological inflammatory disease of slow progression. Other inflammatory diseases such as uveitis, polymyositis, arthritis and alveolitis ${ }^{7}$, as well as infective dermatitis ${ }^{8}$ and some types of skin lesions ${ }^{9}$, are also associated with type 1. Approximately $95 \%$ of HTLV-1 carriers remain asymptomatic throughout their lives, whereas about 5\% develop diseases associated with the virus.

Some studies have reported cases of HAM/TSPlike manifestations, as well as greater susceptibility to bacterial infections, in carriers of HTLV-2 ${ }^{10}$.

HTLV- 1 and 2 are transmitted sexually and vertically (by breastfeeding) ${ }^{11}$, as well as being transmitted parenterally, by contaminated blood transfusion ${ }^{12}$, sharing of contaminated needles and syringes ${ }^{13}$, or transplantation of infected organs and tissues $^{14}$.

Viral types 1 and 2 are endemic in Brazil. The prevalence of HTLV-1 varies between the geographical regions of the country and is generally present in urban population groups ${ }^{15}$. HTLV-2 is more prevalent 
in Indian tribes, although it is also found in urban populations, particularly among intravenous drug users ${ }^{16}$. Blood donor screening for HTLV was introduced in Brazil in November 1993.

According to the Brazilian standard, screening for HTLV-1/2 among blood donors must be done by a highly sensitive test such as an enzyme-linked immunosorbent assay (EIA) or a chemical luminescence test. Use of a second test to confirm the reactivity of a sample is not mandatory. The majority of blood banks use EIA as screening test for HTLV-1/2. If the test result is positive or indeterminate, the sample is tested again using EIA in duplicate. If it remains positive or indeterminate, the associated blood products are discarded. The donor is asked to provide a second sample, and if it is EIA-positive or indeterminate, a Western blot (WB) test is used to confirm the serological status. This algorithm has a high cost, making the use of WB unviable for many Brazilian blood centers. In addition, it generates a relatively high rate of inconclusive results, due especially to the indeterminate nature of WB results ${ }^{17-20}$.

Detection of the viral genome of samples using PCR is a gold standard with high sensitivity and specificity. Its use, which was initially restricted to research studies, is becoming more and more applicable to routine services due to reductions in the costs of molecular biology reagents and the introduction of real-time PCR methods. Several studies have described different real-time PCR protocols for HTLV-1/2 with the aim of quantifying the proviral load ${ }^{21-23}$, which is considered to be a risk marker for the development of virus-associated diseases.

Differently from the previous studies, we evaluated the performance of two qualitative real-time PCR protocols for specific detection of HTLV-1 and HTLV-2 that might present high sensitivity and low cost, in order to increase the viability of their use as routine confirmatory tests in blood banks.

\section{METHODS}

\section{Samples}

We tested a total of 318 blood samples collected in Vacutainer ${ }^{\circledR}$ tubes containing EDTA. One hundred and fifty-two (47.7\%) samples were obtained from blood donors whose initial test results had been EIA-positive or indeterminate for HTLV-1/2, and who returned to the Hemominas Foundation to have a second sample collected and tested by EIA and WB. The remaining 166 (52.3\%) samples were from GIPH (Interdisciplinary HTLV Research Group) cohort participants. This cohort is following up HTLV-positive/ indeterminate blood donors at the Blood Center of Belo Horizonte (part of the Hemominas Foundation), and also includes seronegative blood donors and HAM/TSP patients from the Sarah Network of Rehabilitation Hospitals (Belo Horizonte, State of Minas Gerais). The samples from the cohort included asymptomatic carriers $(\mathrm{n}=108)$, HAM/TSP patients $(\mathrm{n}=26)$, and seronegative individuals $(\mathrm{n}=30)$, along with two individuals whose serological tests were inconclusive (EIA positive/WB indeterminate).

\section{Serological tests for HTLV-1/2}

During the study period (2007 to 2008), two HTLV-1/2 EIA kits were used for screening tests: Murex HTLV-I+II (Murex Biotech Ltd, UK) and Ortho HTLV-I/HTLV-II Ab-Capture ELISA Test System (Ortho Clinical Diagnostics Inc., USA). These kits use recombinant antigens and synthetic peptides, respectively. The tests were conducted in accordance with the manufacturer's instructions. Serum samples with OD/CO (optical density sample/cutoff) lower than 0.8 were considered negative. Results between 0.8 and 1.2 were deemed indeterminate, and results greater than or equal to 1.2 were considered positive for HTLV-1/2. A WB kit (WB HTLV 2.4, Genelabs Diagnostics, USA) was used as a confirmatory test and the results were interpreted in accordance with the manufacturer's criteria, as follows: (1) HTLV-1 positive: GAG reactivity (p19 with or without p24) and two ENV bands (GD21 and rgp46-I); (2) HTLV-2 positive: GAG reactivity (p24 with or without $\mathrm{p} 19$ ) and two ENV bands (GD21 and rgp46-II); (3) HTLV-positive without virus type: GAG reactivity (p19 and p24) and ENV (GD21); (4) indeterminate: detection of specific bands without fulfilling the criteria of positivity for HTLV-1/2; or (5) negative: without reactivity for any specific HTLV bands.

\section{Real-time PCR for HTLV-1 and 2}

Peripheral blood DNA was extracted and purified in columns (QIAamp DNA Blood kit, QIAGEN GmbH, Hilden, Germany), in accordance with the manufacturer's instructions. We performed two qualitative molecular tests for specific detection of HTLV-1 and HTLV-2, using real-time PCR with TaqMan chemistry. One reaction was designed to detect both HTLV-1 and the human albumin gene. Because this was a qualitative assay, human gene amplification was used as a control for amplification of the DNA sample and not for estimating the input of the cells present in each sample. The primers and probe for the albumin gene amplification were applied at a lower concentration than that used to amplify the viral gene, in order to avoid competition for reagents during the reaction. HTLV-2 detection was performed in a separate reaction vessel, but using the same HTLV-1 PCR temperature conditions, which enabled testing for both virus types simultaneously.

The primers and probes were as previously described ${ }^{24}$. DNA $(5 \mu \mathrm{ml})$ was used in the HTLV-1 reaction, presenting a final volume of $25 \mu \mathrm{l}$ consisting of $12.5 \mu \mathrm{l}$ of TaqMan PCR Master Mix (Applied Biosystems, CA, USA), 250nM of HTLV-1F (5'-GAACGCTCTAATGGCATTCTTAAAACC-3'), 250nM of HTLV-1R (5'-GTGGTTGATTGTCCATAGGGCTAT-3') and 200nM of HTLV-1P (5'-FAM-ACAAACCCGACCTACCC-MGB-3') for HTLV-1 pol region amplification; and 150nM of ALB-F (5'-GCTCAACTCCCTATTGCTATCACA-3'), 150nM of ALB-R (5'-GGGCATGACAGGTTTTGCAATATTA-3') and 100nM of ALB-P (5'-VIC-TTGTGGGCTGTAATCAT-MGB-3') for human albumin gene amplification.

The reaction to detect HTLV-2 (pol region) was performed using $5 \mu \mathrm{l}$ of DNA in a volume of $25 \mu \mathrm{l}$ containing $12.5 \mu \mathrm{l}$ of TaqMan PCR Master Mix (Applied Biosystems, CA, USA), 250nM of HTLV2F (5'-CAACCCCACCAGCTCAGG-3'), 250nM of HTLV-2R (5'-GGGAAGGTTAGGACAGTCTAGTAGATA-3') and 250nM of HTLV-2P (5'-FAM-TCGAGAGAACCAATGGTATAAT-MGB- 3').

Both reactions were performed in the $A B I$ 7,300 apparatus (Applied Biosystems, CA, USA), under the following cycle conditions: $2 \mathrm{~min}$ at $50^{\circ} \mathrm{C}$ and $10 \mathrm{~min}$ at $95^{\circ} \mathrm{C}$, followed by 45 cycles of $15 \mathrm{~s}$ at $95^{\circ} \mathrm{C}$ and $1 \mathrm{~min}$ at $60^{\circ} \mathrm{C}$. DNA from the MT2 cell line, which has a complete proviral copy integrated in the genome of the cell and other defective proviral sequences, was used as a positive control for the HTLV-1 assay. For HTLV-2, a plasmid containing an HTLV-2 DNA sequence was utilized as a positive control. DNA samples from two seronegative individuals were used as negative controls, in addition to the "mix" control, without the addition of DNA. 


\section{Ethics committee approval}

This study was approved by the Ethics Committee for Research Involving Human Beings of the Hemominas Foundation.

\section{RESULTS}

The real-time PCR results for HTLV-1 and HTLV-2 from the 318 samples tested are shown in Table 1, according to the serological results. Taking into account the samples that were WB-positive $(\mathrm{n}=174)$ or negative $(\mathrm{n}=39)$, and the ones that were EIA-negative $(\mathrm{n}=96)$ but were not tested using WB, the sensitivity and specificity of the PCR were $99.4 \%$ and $98.5 \%$, respectively.

TABLE 1 - Real-time PCR results for HTLV-1 and HTLV-2, according to serological results of the analyzed samples.

\begin{tabular}{lccccc}
\hline & EIA neg & $\begin{array}{c}\text { EIA ind } \\
\text { WB neg }\end{array}$ & $\begin{array}{c}\text { EIA pos } \\
\text { WB neg }\end{array}$ & $\begin{array}{c}\text { EIA pos } \\
\text { WB pos }\end{array}$ & $\begin{array}{c}\text { EIA pos } \\
\text { WB ind }\end{array}$ \\
Real-time PCR & 0 & 0 & 0 & 39 & 1 \\
\hline Donors & 0 & 0 & 2 & 1 & 0 \\
HTLV-1 pos & 66 & 18 & 19 & 0 & 6 \\
HTLV-2 pos & 0 & 0 & 0 & 130 & 1 \\
HTLV-1 and 2 neg & 0 & 0 & 0 & 3 & 0 \\
GIPH cohort & 30 & 0 & 0 & 1 & 1 \\
HTLV-1 pos & $\mathbf{9 6}$ & $\mathbf{1 8}$ & $\mathbf{2 1}$ & $\mathbf{1 7 4}$ & $\mathbf{9}$ \\
HTLV-2 pos & & & & & \\
HTLV-1 and 2 neg & & &
\end{tabular}

pos: positive, neg: negative, ind: indeterminate.

EIA: enzyme-linked immunosorbent assay, WB: Western blot, GIPH: Interdisciplinary HTLV Research Group.

We found only one false-negative PCR result. This was from a sample from a GIPH cohort participant, an asymptomatic 38-year-old male whose EIA and WB tests done in 2004 and 2008 were positive for HTLV-1. The samples collected in 2004, 2007 and 2008 were tested by means of nested PCR for HTLV-1 at the time of collection, but they were negative. The last sample collected from this individual (in 2008) was tested using real-time PCR, but it was also negative.

Two other results were discordant between the molecular and WB tests. In these cases, the samples were EIA-positive (OD/CO of 25.1 and 2.5), but with a negative result from WB. We tested these samples twice using PCR and they were both negative for HTLV-1 and positive for HTLV-2, thus suggesting that WB failed to detect the type 2 virus.

We also analyzed nine samples that were EIA-positive and WBindeterminate. Seven were negative for HTLV-1 and 2 using PCR, while two were positive for HTLV-1. One of these samples was from a GIPH cohort participant who had been followed up. As shown in Table 2, he had been tested three times using EIA and WB over a five-month period, maintaining the indeterminate pattern on WB. Nevertheless, PCR confirmed the presence of virus infection in his first sample.

Out of the 40 blood donor samples that were both EIA and WBpositive (excluding the two individuals who were WB-negative and PCR-positive for HTLV-2), two (5\%) did not present reactivity on WB for either of the recombinant proteins (rgp46-I and rgp46-II) that define whether the infection consists of HTLV type 1 or type 2, respectively. This discrimination was possible through using PCR, such that both samples yielded positive results for HTLV-1.
TABLE 2 - Serological and molecular results for HTLV-1 and 2 on an individual in the GIPH cohort with HTLV-indeterminate WB results, Belo Horizonte, Brazil.

\begin{tabular}{lcccc}
\hline & & & \multicolumn{2}{c}{ Real-time PCR } \\
\cline { 4 - 5 } Date & EIA (OD/CO)* & WB & HTLV-1 & HTLV-2 \\
\hline Nov 23, 2007 & positive (6.1) & GD21 + rgp46-I & not done & not done \\
Feb 11,2008 & positive (8.5) & GD21 + rgp46-I & positive & negative \\
Apr 17, 2008 & positive (6.9) & GD21 + rgp46-I & positive & negative \\
\hline
\end{tabular}

${ }^{*} \mathrm{OD} / \mathrm{CO}$ : optical density/sample cutoff, EIA: enzyme-linked immunosorbent assay, WB: Western blot.

Among the asymptomatic carriers and HAM/TSP patients from the GIPH cohort, only three (1.7\%) were positive for HTLV-2 on PCR; all the rest (98.3\%) being identified as infected by HTLV-1. In the 42 blood donors who were PCR positive, we identified three cases $(7.1 \%)$ of HTLV-2 infection (two of which were not detected on $\mathrm{WB})$, and all the remaining cases (92.9\%) showed evidence of infection by type 1 virus (HTLV-1).

\section{DISCUSSION}

In order to diagnose HTLV infections, both the ability to detect them and the capability to differentiate between types 1 and 2 are required. The strategies currently used in Brazilian blood banks for such detection are based on serological tests (EIA followed by WB). The development of new EIA kits for HTLV that use recombinant proteins and synthetic peptides has increased the sensitivity and specificity of such kits, in comparison with kits that use viral lysate ${ }^{25-27}$. In contrast, the WB test for HTLV-1/2 has shown little development over recent years, and is unsuitable for blood banks because of its high costs and high proportion of indeterminate results ${ }^{28-32}$. This situation suggests that there is a need to confirm virus infection by means of molecular tests.

In this study, we evaluated two qualitative analyses for HTLV proviral DNA, using real-time PCR. The assays proved to be highly sensitive and specific for HTLV-1 and 2 in the great majority of samples. The results indicated that WB failed to detect infection by HTLV type 2, and this was also observed in two other cases that were not included in this study. Previous studies have shown that the confirmatory sensitivity of WB for HTLV-2 is worse than for HTLV- 1 and presents a greater frequency of indeterminate or false negative results ${ }^{28-31}$

Two (5\%) out of the $40 \mathrm{WB}$-positive samples from blood donors did not present reactivity in the WB test for either of the recombinant proteins (rgp46-I or rgp46-II). This distinction was only possible through using the PCR, thus showing one more advantage of the PCR test in comparison with WB. In addition to confirmation of the presence of the virus, it is very important to differentiate between HTLV- 1 and HTLV-2, because the virus types present associations with different outcome diseases.

Controversy surrounds the interpretation of indeterminate WB patterns because of the inability to correctly define positive and negative cases from such patterns. Indeterminate $\mathrm{WB}$ profiles are a problem for blood banks, because they lead to discarding of blood components and rejection of donors as unsuitable for future blood donations. Such results are disturbing for the donors, as they are left without any definition regarding their true status (infected or uninfected). This situation generates great difficulty 
in donor counseling. In general, indeterminate WB findings do not represent current HTLV infection ${ }^{33}$, but in high-risk populations or in endemic areas, an indeterminate WB result may represent a case at the seroconversion stage ${ }^{20,34}$. By using real-time PCR in the present study, we found nine samples that were EIA-positive and WB-indeterminate, and two of them (22.2\%) were positive for HTLV-1. The data showed that PCR was able to define cases with inconclusive serological tests, thereby identifying the current viral infection status, because proviral DNA can be detected before an immune response intense enough to be detected in the WB serological test has developed. The proportion of true positive individuals among the indeterminate cases emphasizes the need for caution when considering the indeterminate cases in our population as false-reactive ones.

Countries such as France, Germany and the USA have introduced NAT (nucleic acid testing) for identifying the HIV and HCV genomes during blood donor screening, with the objective of diminishing the immunological window and increasing the safety of transfusions. Unlike the use of NAT for HIV and HCV, we proposed the use of PCR for HTLV testing in routine blood donor screening, only for confirmatory tests on samples that are EIA-positive or indeterminate. Replacing WB with PCR would lead to improvement of the sensitivity and reduction of the costs of the screening. Thus, our approach was to develop a qualitative assay, differently from many real-time PCR tests, which were designed to quantify the proviral load of HTLV-1/2. Because of the sensitivity, simplicity, rapidity in obtaining results and lower cost (approximately one tenth of the cost of WB) of real-time PCR, qualitative PCR assays for HTLV- 1 and 2 were shown to be viable as confirmatory tests in blood banks.

\section{ACKNOWLEDGMENTS}

Dr. Sam Charache for critically reviewing the manuscript, and the members of GIPH for their cooperation.

\section{CONFLICT OF INTEREST}

The authors declare that there is no conflict of interest.

\section{FINANCIAL SUPPORT}

Research Support Foundation of the State of Minas Gerais (Fundação de Amparo à Pesquisa do Estado de Minas Gerais; FAPEMIG) and the Hemominas Foundation.

\section{REFERENCES}

1. Proietti FA, Carneiro-Proietti AB, Catalan-Soares BC, Murphy EL. Global epidemiology of HTLV-I infection and associated diseases. Oncogene 2005; 24:6058-6068.

2. Hall WW, Kubo T, Ijichi S, Takahashi H, Zhu SW. Human T-cell leukemia/ lymphoma virus, type II (HTLV-II): emergence of an important newly recognized pathogen. Sem Virol 1994; 5:165-178.

3. Maloney E, Biggar RJ, Neel JV, Taylor ME, Hahn BH, Shaw GM, et al. Endemic human $\mathrm{T}$ cell lymphotropic virus type II infection among isolate Brazilian amerindians. J Infect Dis 1992; 166:100-107.

4. Mahieux R, Gessain A. The human HTLV-3 and HTLV-4 retroviruses: new members of the HTLV family. Pathol Biol 2009; 57:161-166.
5. Tsukasaki K, Hermine O, Bazarbachi A, Ratner L, Ramos JC, Harrington Jr W, et al. Definition, prognostic factors, treatment, and response criteria of adult T-cell leukemia-lymphoma: a proposal from an international consensus meeting. J Clin Oncol 2009; 27:453-459.

6. De Castro-Costa CM, Araújo AQ, Barreto MM, Takayanagui OM, Sohler MP, da Silva EL, et al. Proposal for diagnostic criteria of tropical spastic paraparesis/ HTLV-I-associated myelopathy (TSP/HAM). AIDS Res Hum Retroviruses 2006; 22:931-935.

7. Carneiro-Proietti AB, Ribas JG, Catalan-Soares BC, Martins ML, Brito-Melo GE, Martins-Filho AO, et al. Infecção e doença pelo vírus linfotrópicos humanos de células T (HTLV-I/II) no Brasil. Rev Soc Bras Med Trop 2002; 35:499-508.

8. Farre L, de Oliveira MF, Primo J, Vandamme AM, Van Weyenbergh J, Bittencourt AL. Early sequential development of infective dermatitis, human $\mathrm{T}$ cell lymphotropic virus type 1-associated myelopathy, and adult $\mathrm{T}$ cell leukemia/ lymphoma. Clin Infect Dis 2008; 46:440-442.

9. Nobre V, Guedes AC, Proietti FA, Martins ML, Nassif G, Serufo JC, et al. Increased prevalence of human $\mathrm{T}$ cell lymphotropic virus type 1 in patients attending a Brazilian dermatology clinic. Intervirology 2007; 50:316-318.

10. Roucoux DF, Murphy EL. The epidemiology and disease outcomes of human T-lymphotropic virus type II. AIDS Rev 2004; 6:144-154.

11. Take H, Umemoto M, Kusuhara K, Kuraya K. Trasmission routes of HTLV-I: an analysis of 66 families. Jpn J Cancer Res 1993; 84:1265-1267.

12. Okochi K, Sato H, Hinuma Y. A retrospective study on transmission of adult T-cell leukemia virus by blood transfusion: seroconversion in recipients. Vox Sang $1984 ; 46: 245-253$.

13. Manns A, Miley WJ, Wilks RJ, Morgan OS, Hanchard B, Wharfe G, et al. Quantitative proviral DNA and antibody levels in the natural history of HTLV-I infection. J Infect Dis 1999; 180:1487-1493.

14. Zarranz Imirizaldu JJ, Gomez Esteban JC, Rouco Axpe I, Perez Concha T, Velasco Juanes F, Allue Susaeta I, et al. Post-transplantation HTLV-1 myelopathy in three recipients from a single donor. J Neurol Neurosurg Psychiatry 2003; 74:10801084.

15. Catalan-Soares B, Carneiro-Proietti ABF, Proietti FA. Heterogeneous geographic distribution of human T-cell lymphotropic viruses I and II (HTLV-I/II): serological screening prevalence rates in blood donors from large urban areas in Brazil. Cad Saúde Pública 2005; 21:926-931.

16. Alcantara LC, Shindo N, Van Dooren S, Salemi M, Costa MC, Kashima S, et al. Brazilian HTLV type 2a strains from intravenous drug users (IDUs) appear to have originated from two sources: Brazilian Amerindians and European/North American IDUs. AIDS Res Hum Retroviruses 2003; 19:519-523.

17. Berini CA, Eirin ME, Pando MA, Biglione MM. Human T-cell lymphotropic virus types I and II (HTLV-I and -II) infection among seroindeterminate cases in Argentina. J Med Virol 2007; 79:69-73.

18. Césaire R, Bera O, Maier H, Lezin A, Martial J, Ouka M, et al. Seroindeterminate patterns and seroconversions to human T-lymphotropic virus type I positivity in blood donors from Martinique, French West Indies. Transfusion 1999; 39: 11451149 .

19. Jacob F, Santos-Fortuna E, Azevedo RS, Caterino-de-Araújo A. Performances of HTLV serological tests in diagnosing HTLV infection in high-risk population of São Paulo, Brazil. Rev Inst Med Trop São Paulo 2007; 49:361-364.

20. Mauclère P, Le Hesran JY, Mahieux R, Salla R, Mfoupouendoun J, Abada ET, et al. Demographic, ethnic, and geographic differences between human $\mathrm{T}$ cell lymphotropic virus (HTLV) type I-seropositive carriers and persons with HTLV-I Gag-indeterminate Western blots in Central Africa. J Infect Dis 1997; 176:505-509.

21. Kamihira S, Dateki N, Sugahara K, Hayashi T, Harasawa H, Minami S, et al. Significance of HTLV-1 proviral load quantification by real time PCR as a surrogate marker for HTLV-1-infected cell count. Clin Lab Haematol 2003; 25:111-117.

22. Lee T-H, Chafets DM, Busch MP, Murphy EL. Quantitation of HTLV-I and II proviral load using real time quantitative PCR with SYBR Green chemistry. J Clin Virol 2004; 31:275-282.

23. Olindo S, Lézin A, Cabre P, Merle H, Saint-Vil M, Edimonana Kaptue M, et al. HTLV-1 proviral load in peripheral blood mononuclear cells quantified in 100 HAM/TSP patients: a marker of disease progression. J Neurol Sci 2005; 237:5359. 
24. Tamegão-Lopes BP, Rezende PR, Maradei-Pereira LMC, Lemos JAR. Carga proviral do HTLV-1 e HTLV-2: um método simples através da PCR quantitativa em tempo real. Rev Soc Bras Med Trop 2006; 39:548-552.

25. Andersson S, Thorstensson R, Ramirez KG, KrookA, von Sydow M, Dias F, et al. Comparative evaluation of 14 immunoassays for the detection of antibodies to the human T-lymphotropic virus types I and II using panels of sera from Sweden and West Africa. Transfusion 1999; 39:845-851.

26. Thorstensson R, Albert J, Andersson S. Strategies for diagnosis of HTLV-I and HTLV-II. Transfusion 2002; 42:780-791.

27. Vrielink H, Reesink H, Habibuw M, Schuller M, van der Meer C, Lelie P. Comparison of four HTLV-I and HTLV-I + II ELISAs. Vox Sang 1999; 76:187191.

28. Liu H, Shah M, Stramer SL, Chen W, Weibblen BJ, Murphy EL. Sensitivity and specificity of human T-lymphotropic virus (HTLV) types I and II polymerase chain reaction and several serologic assays in screening a population with a high prevalence of HTLV-I/II. Transfusion 1999; 39:1185-1193.

29. Morimoto HK, Morimoto AA, Reiche EM, Ueda LT, Matsuo T, Reiche FV, et al. Difficulties in the diagnosis of HTLV-2 infection in HIV/AIDS patients from Brazil: comparative performances of serologic and molecular assays, and detection of HTLV-2b subtype. Rev Inst Med Trop São Paulo 2007; 49:225-230.

30. Poiesz BJ, Dube S, Choi D, Esteban E, Ferrer J, Leon-Ponte M, et al. Comparative perfomances of an HTLV-I/II EIA and other serologic and PCR assays on samples from persons at risk for HTLV-II infection. Transfusion 2000; 40:924-930.

31. Zehender G, De Maddalena C, Gianotto M, Cavalli B, Santambrogio S, Orso M, et al. High prevalence of false-negative anti-HTLV type I/II enzymelinked immunosorbent assay results in HIV type I-positive patients. AIDS Res Human Retrovirol 1997; 13:1141-1146.

32. Zaaijer HL, Cuypers HTM, Dudok De Wit C, Lelie PN. Results of 1-year screening of donors in the Netherlands for human T-lymphotropic virus (HTLV) type I: significance of Western blot patterns for confirmation of HTLV infection. Transfusion 1994; 34:877-880.

33. Busch MP, Switzer WM, Murphy EL, Thomson R, Heneine W. Absence of evidence of infection with divergent primate T-lymphotropic viruses in United States blood donors who have seroindeterminate HTLV test results. Transfusion 2000; 40:443-449.

34. Medrano FJ, Soriano V, Calderón EJ, Rey C, Gutiérrez M, Bravo R, et al. Significance of indeterminate reactivity to human T-cell lymphotropic virus in Western blot analysis of individuals at risk. Eur J Clin Microbiol Infect Dis 1997; $16: 249-252$. 